\title{
Front Matter: Volume 11357
}

, "Front Matter: Volume 11357," Proc. SPIE 11357, Fiber Lasers and Glass Photonics: Materials through Applications II, 1135701 (8 May 2020); doi: $10.1117 / 12.2571827$

SPIE. Event: SPIE Photonics Europe, 2020, Online Only 


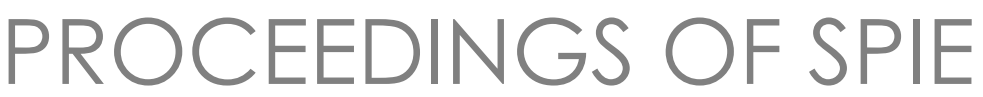

\title{
Fiber Lasers and Glass Photonics: Materials through Applications II
}

\author{
Maurizio Ferrari \\ Jacob I. Mackenzie \\ Stefano Taccheo \\ Editors \\ 6-10 April 2020 \\ Online Only, France \\ Sponsored by \\ SPIE \\ Cosponsored by \\ City of Strasbourg (France) \\ Eurometropole (France) \\ CNRS (France) \\ Région Grand Est (France) \\ iCube (France) \\ Université de Strasbourg (France) \\ Cooperating Organisations \\ Photonics 21 (Germany) \\ EOS-European Optical Society (Germany) \\ Photonics Public Private Partnership (Belgium) \\ Photonics France (France) \\ Published by \\ SPIE
}


The papers in this volume were part of the technical conference cited on the cover and title page. Papers were selected and subject to review by the editors and conference program committee. Some conference presentations may not be available for publication. Additional papers and presentation recordings may be available online in the SPIE Digital Library at SPIEDigitalLibrary.org.

The papers reflect the work and thoughts of the authors and are published herein as submitted. The publisher is not responsible for the validity of the information or for any outcomes resulting from reliance thereon.

Please use the following format to cite material from these proceedings:

Author(s), "Title of Paper," in Fiber Lasers and Glass Photonics: Materials through Applications II, edited by Maurizio Ferrari, Jacob I. Mackenzie, Stefano Taccheo, Proceedings of SPIE Vol. 11357 (SPIE, Bellingham, WA, 2020) Seven-digit Article CID Number.

ISSN: 0277-786X

ISSN: 1996-756X (electronic)

ISBN: 9781510634862

ISBN: 9781510634879 (electronic)

Published by

SPIE

P.O. Box 10, Bellingham, Washington 98227-0010 USA

Telephone +1 3606763290 (Pacific Time) · Fax +1 3606471445

SPIE.org

Copyright (C) 2020, Society of Photo-Optical Instrumentation Engineers.

Copying of material in this book for internal or personal use, or for the internal or personal use of specific clients, beyond the fair use provisions granted by the U.S. Copyright Law is authorized by SPIE subject to payment of copying fees. The Transactional Reporting Service base fee for this volume is $\$ 21.00$ per article (or portion thereof), which should be paid directly to the Copyright Clearance Center (CCC), 222 Rosewood Drive, Danvers, MA 01923. Payment may also be made electronically through CCC Online at copyright.com. Other copying for republication, resale, advertising or promotion, or any form of systematic or multiple reproduction of any material in this book is prohibited except with permission in writing from the publisher. The CCC fee code is 0277$786 \mathrm{X} / 20 / \$ 21.00$.

Printed in the United States of America by Curran Associates, Inc., under license from SPIE.

Publication of record for individual papers is online in the SPIE Digital Library.

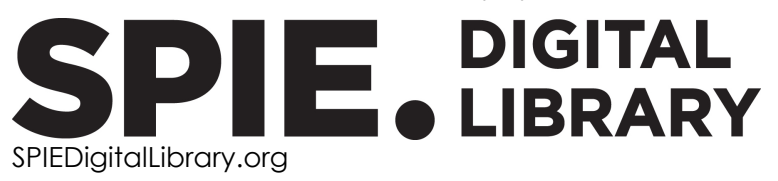

Paper Numbering: Proceedings of SPIE follow an e-First publication model. A unique citation identifier (CID) number is assigned to each article at the time of publication. Utilization of CIDs allows articles to be fully citable as soon as they are published online, and connects the same identifier to all online and print versions of the publication. SPIE uses a seven-digit CID article numbering system structured as follows:

- The first five digits correspond to the SPIE volume number.

- The last two digits indicate publication order within the volume using a Base 36 numbering system employing both numerals and letters. These two-number sets start with 00, 01, 02, 03, 04, 05, 06, 07, 08, 09, OA, OB ... 0Z, followed by 10-1Z, 20-2Z, etc. The CID Number appears on each page of the manuscript. 


\title{
Contents
}

\author{
vii Authors \\ xi Conference Committee
}

\section{FLEXIBLE PHOTONICS}

$1135705 \quad$ Flexible photonics: RF-sputtering fabrication of glass-based systems operating under mechanical deformation conditions [11357-3]

1135706 Flexible sol-gel coatings on polymeric and metallic materials [11357-4]

\section{GLASS CERAMICS}

1135707 Strengthened glass by ion exchange, mechanical and optical properties: perspectives and limits of glass as a substrate for flexible photonics (Invited Paper) [11357-77]

$1135708 \quad$ Novel ER ${ }^{3+}$ doped tellurite glass-ceramics [1 1357-6]

1135709 Design of active devices based on rare-earth-doped glass/glass ceramic: from the material characterization to the device parameter refinement [11357-7]

11357 OA Luminescent properties of chromium-doped borate glass-ceramics for red radiation sources [11357-8]

\section{GLASS CERAMICS AND SHORT-RANGE ORDERED MATERIALS}

$11357 \mathrm{OB}$ Tunable upconversion emission in NaLuF 4 -glass-ceramic fibers doped with $\mathrm{Er}^{3+}$ and $\mathrm{Yb}^{3+}$ (Invited Paper) [11357-9]

$11357 \mathrm{OE}$ Microstructure, absorption and luminescence of $\mathrm{Co}^{2+}: \mathrm{ZnAl}_{2} \mathrm{O}_{4}$ transparent ceramics: effect of sintering additive [1 1357-12]

11357 OF Generation of narrow modes within incoherent radiation of random distributed feedback fiber laser [11357-13]

\section{RE-DOPED MATERIAL LASERS AND FIBERS}

$11357 \mathrm{OH} \quad$ Spectroscopy and laser operation of $\mathrm{Tm}^{3+}: \mathrm{YAIO}_{3}$ crystal on the ${ }^{3} \mathrm{H}_{4} \rightarrow{ }^{3} \mathrm{H}_{5}$ transition [1 1357-15] 
$11357 \mathrm{Ol} \quad$ Neodymium and ytterbium-erbium laser based on photo-thermo-refractive glass [11357-17]

11357 OJ Modeling mode-locked Bismuth laser for soliton generation in the normal and anomalous dispersion regime [11357-18]

11357 OK Investigation of the wavelength dependency of the creation of sub-surface modifications in ZnS [11357-19]

RE-DOPED MATERIAL SPECTROSCOPY: GLASSES AND CRYSTAL

$11357 \mathrm{OL} \quad$ Spectral and time-resolved analysis of rare earth-doped $\mathrm{SnO}_{2}$ emission (Invited Paper) [1 1357-20]

$11357 \mathrm{ON} \quad$ Cross-relaxation and ion clustering in $\mathrm{Tm}^{3+} \mathbf{C a F}_{2}$ crystals [11357-23]

11357 OP Thermal stability of bismuth-doped high-GeO ${ }_{2}$ fiber lasers [1 1357-25]

NONLINEAR PHENOMENA IN FIBRES AND LASERS

11357 OR Brillouin light scattering characterization of optical materials [1 1357-27]

11357 OS Optical frequency combs generation with collinear acousto-optic interaction [1 1357-28]

11357 OT Chirped pulse compression in all-glass Yb-doped hybrid fiber with anomalous dispersion in $1 \mu \mathrm{m}$ spectral range [11357-29]

11357 OU Elaboration of multimaterials optical fibers combining tellurite glass and metal for electrooptical applications [1 1357-30]

WAVEGUIDE DEVICES AND FIBERS

11357 OW Thermo-optic effects in multicore fibers for high-power lasers (Invited Paper) [11357-32]

11357 OY Integrated fiber components based on chirally-coupled-core fibers for all-fiber amplifier [1 1357-34]

FIBER LASERS: FROM IR TO MIR

$11357 \mathrm{OZ} \quad$ Mid-IR supercontinuum in optical fibers drawn from low phonon energy glasses (Invited Paper) [1 1357-35]

iv 
1135710 Mid-infrared sources for biomedical applications based on chalcogenide glass fibres (Invited Paper) [11357-76]

$1135711 \quad$ All-fiber mode-locked laser at 977 nm [11357-37]

\section{2-MICRON FIBER LASERS: JOINT SESSION I}

$1135713 \quad$ Ultra-short pulsed fiber-based lasers around $2.1 \mu \mathrm{m}$ and their applications (Invited Paper) [11357-40]

1135714 Tunable fiber laser concepts in the $2 \mu \mathrm{m}$ spectral range for tunable dual wavelength emission (Invited Paper) [11357-41]

1135715 nJ-class all-PM fiber tunable femtosecond laser from $1800 \mathbf{n m}$ to $2050 \mathrm{~nm}$ via a highly efficient SSFS [11357-42]

\section{APPLICATIONS AND PROCESSES}

1135717 Biomedical applications of functionalized optical fibre long period grating sensors (Invited Paper) [11357-44]

1135718 Simultaneous OFDR spatial multiplexing by means of nanoparticle doped optical fibers, theory and sensing applications (Invited Paper) [11357-45]

1135719 FLY-SPEC prototype: UV-VIS-NIR reflectometry and laser induced breakdown spectroscopy [11357-46]

MATERIALS AND FIBERS: CHARACTERIZATION, FABRICATION AND APPLICATIONS

11357 1B Optical fibers under irradiation: quantitative assessment of the energy distribution of radiationinduced trapped states (Invited Paper) [1 1357-48]

$113571 \mathrm{C} \quad$ Characterization and afterglow of $\mathrm{SrAl}_{2} \mathrm{O}_{4}: \mathrm{Eu}, \mathrm{Dy}$ for various phosphor applications (Invited Paper) [11357-49]

11357 ID Shaping effects of the fiber-drawing on particle-rich silica optical fibers, numerical and experimental study [11357-50]

\section{NOVEL MATERIALS AND DEVICES}

$113571 G \quad$ Ultrafast photochromism and bacteriochromism in one dimensional hybrid plasmonic photonic structures (Invited Paper) [1 1357-53] 
$113571 \mathrm{~K} \quad$ Glassy 2-(1-benzyl-2-styryl-6-methylpyridin-4(1H)-ylidene) fragment containing $1 \mathrm{H}$-indene$1,3(2 \mathrm{H})$-dione and pyrimidine-2,4,6(1H,3H,5H)-trione derivatives with light-emitting and amplified spontaneous emission properties [11357-55]

$11357 \mathrm{lL} \quad$ Channel waveguide lasers in bulk Tm:LiYF 4 crystal produced by deep diamond-saw dicing [11357-56]

11357 1M Recursive calculation of exact electric-field and intensity distributions in Bragg-grating mirrors and distributed-feedback-laser structures [11357-57]

11357 IP Optimization of fiber to resonator coupling [11357-60]

11357 1Q Narrow linewidth random laser based on short Er-doped artifice Rayleigh fiber [11357-61]

11357 is Design and fabrication of multilayer-driven optomechanical device for force and vibration sensing [11357-65]

11357 IT Efficient laser operation in cleaved single-crystal plates of $\mathrm{Yb}: \mathrm{KY}\left(\mathrm{MoO}_{4}\right)_{2}$ : a novel molybdate compound [11357-66]

11357 IV Effect of phosphates content on the spectroscopic properties of the fluorophosphate glasses doped with $\mathbf{N d}^{3+}$ ions [11357-68]

$113571 \mathrm{X}$ Transparent glass-ceramics based on $\mathrm{Co}^{2+}, \mathrm{Ga}^{3+}$-codoped $\mathrm{ZnO}$ nanocrystals: a promising nonlinear optical material [11357-70]

$113571 Y$ Accuracy of the determination of propagation velocities of phononic waves in the material [11357-71] 


\section{Authors}

Numbers in the index correspond to the last two digits of the seven-digit citation identifier (CID) article numbering system used in Proceedings of SPIE. The first five digits reflect the volume number. Base 36 numbering is employed for the last two digits and indicates the order of articles within the volume. Numbers start with 00, 01, 02, 03, 04, 05, 06, 07, 08, 09, 0A, 0B...0Z, followed by 10-12, 20-2Z, etc.

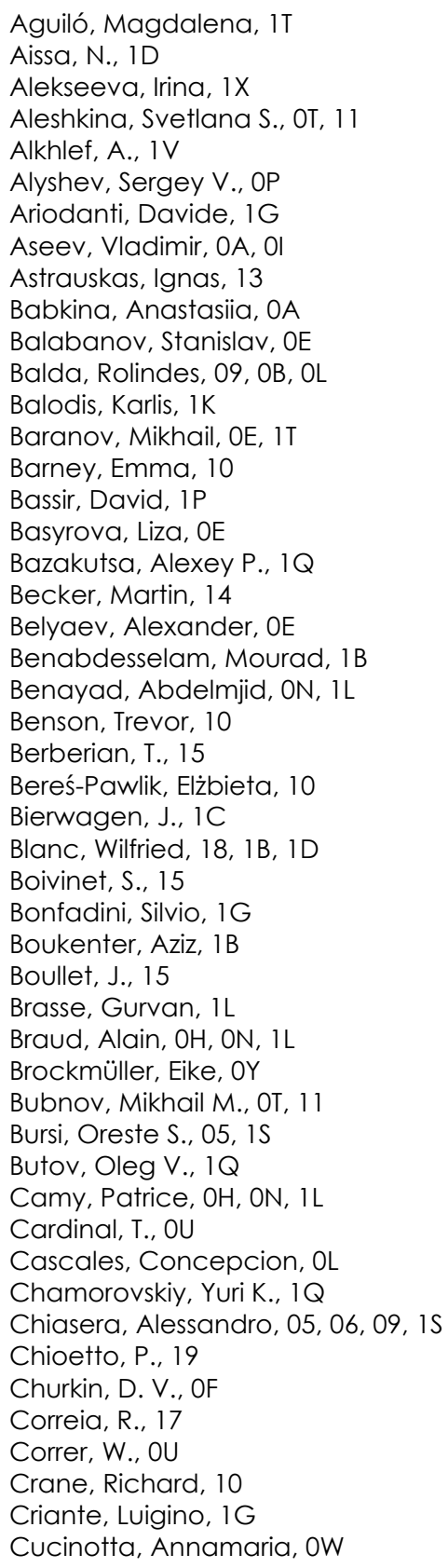

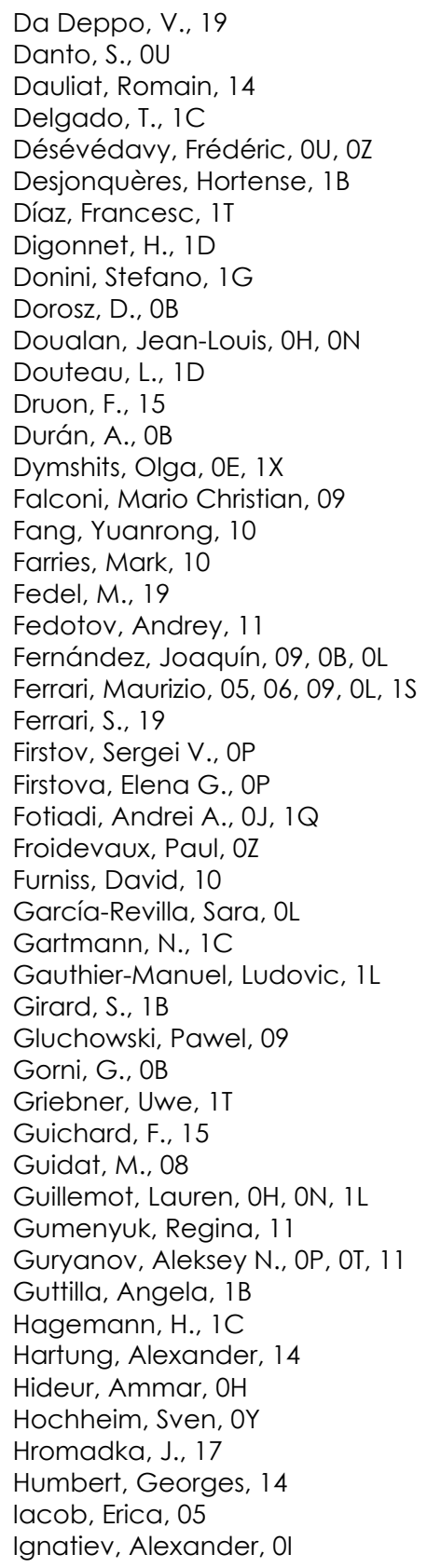


Ivanov, Sergey, 0 I

Jäger, Matthias, 14 Jayasuriya, Dinuka, 10

Jules, J. C., OU

Kharakhordin, Alexandr V., OP

Khegai, Aleksandr M., OP

Khoder, Y., ID

Khopin, Vladimir F., OP

Khubetsov, Alexander, $1 \mathrm{X}$

Kibler, Bertrand, $\mathrm{OZ}$

Kicior, Inga, 06

Kifle, Esrom, $\mathrm{OH}, 1 \mathrm{~L}, 1 \mathrm{~T}$

Kinski, I., $1 \mathrm{C}$

Kochanowicz, M., OB

Kochergina, Tatyana A., 11

Kokars, Valdis, IK

Kolobkova, E., 1V

Koponen, Joona, OY

Korobko, D. A., OJ

Korposh, S., 17

Koselja, Michal, $\mathrm{OH}$

Kotov, Leonid V., 11

Kracht, Dietmar, OY

Kriegel, Ilka, $1 \mathrm{G}$

Krzak, Justyna, 05, 06

Kulpina, Ekaterina, OA

Laneve, Dario, 09

Lanzani, Guglielmo, $1 \mathrm{G}$

Lazdovica, Kristine, $1 \mathrm{~K}$

Leconte, Baptiste, 14

Ledemi, Y., OU

Lelet, Maxim, OE

Lemière, Arnaud, $\mathrm{OU}, \mathrm{OZ}$

Lewandowski, Daniel, 06

Likhachev, Mikhail E., OT, 11

Likhov, V. V., OK

Lipatov, Denis S., OT, 11

Liu, L., 17

Lobanov, Alexey S., OP

Loconsole, Antonella Maria, 09

Loiko, Pavel, $\mathrm{OE}, \mathrm{OH}, \mathrm{ON}, 1 \mathrm{~L}, 1 \mathrm{~T}, 1 \mathrm{X}$

Lowder, Tyson, OY

LU, Z., ID

Łukowiak, Anna, 05, 06, 09, OL, is

Mabwa, David, 10

Machinet, G., 15

Macrelli, Guglielmo, 07

Mady, Franck, 1B

Maldonado, Anthony, OU, OZ

Mantsevich, Sergey N., OS

Massironi, M., 19

Mateos, Xavier, 1T, $1 \mathrm{X}$

Mckee, Seyyedhossein, OW

Melkumov, Mikhail A., OP

Messaddeq, Y., OU

Meyzen, C. M., 19

Misina, Elina, $1 \mathrm{~K}$

Molardi, C., 18

Moncorgé, Richard, $\mathrm{OH}$
Monsanglant-Louvet, Céline, 1B

Morgan, S. P., 17

Morin, P., 15

Moscardi, Liliana, $1 G$

Nasser, Khaldoon, 0

Nava, J., 19

Nestola, F., 19

Neumann, Jörg, OY

Nicolosi, P., 19

Nikonorov, Nikolay, OI, IV

Novotny, Steffen, OY

Nunes, Joel, 10

Nuryev, Rustam, OA

Okhrimchuk, A. G., OK

Osipova, Anastasiia, OA

Ouerdane, Y., 1B

Panajotov, Krassimir, IQ

Parisini, Emilio, $1 G$

Parnell, Harriet, 10

Pascual, M. J., OB

Paternò, Giuseppe M., $1 G$

Pavlyuk, Anatoly, $1 T$

Pervenecka, Julija, $1 \mathrm{~K}$

Petit, L., 08

Petrov, Valentin, $1 \mathrm{~T}$

Phang, Sendy, 10

Poli, Federica, ow

Polishchuk, Anton, 1X

Pollnau, Markus, 1C, $1 \mathrm{M}$

Popov, Sergei M., $1 Q$

Prudenzano, Francesco, 09, OL

Richter, Roland A., OK, 13

Righini, Giancarlo C., 05

Riumkin, Konstantin E., OP

Rocha da Silva, L., ID

Rosa, Lorenzo, OW

Rothhardt, Manfred, 14

Roy, Philippe, 14

Salem, Ezzedine Ben, IT

Salgankii, Mikhail YU., OT

Salzenstein, Patrice, OR, IP, $1 Y$

Sayginer, Osman, 05, is

Scotognella, Francesco, $1 G$

Seddon, Angela B., 10

Selleri, Stefano, OW

Serres, Josep Maria, 1T, 1X

Shchukarev, Igor, OJ

Shemchuk, Daria, IX

Shen, Meili, 10

Shepelev, Denis V., OT

Skogen, Marius, 13

Slemer, A., 19

Slimi, Sami, $1 \mathrm{~T}$

Smayev, M. P., OK

Smektala, Frédéric, $\mathrm{OU}, \mathrm{OZ}$

Sojka, Lukasz, 10

Solé, Rosa Maria, $1 \mathrm{~T}$

Sorokin, Evgeni, OK, 13

Sorokina, Irina T., OK, 13 
Steinke, Michael, OY

Strutynski, C., OU

Sugavanam, S., OF

Sujecki, Slawomir, 10

Szalkowska, Marta, 06

Szczurek, Anna, 05, 06

Tang, Zhuoqi, 10

Tausenev, Anton $\vee$., OT

Temyanko, Valery L., 11

Tiess, Tobias, 14

Tolstik, Nikolai, OK, 13

Tosi, D., 18

Tran, Lam Thi Ngoc, 09, OL

Tsenter, Marina, IX

Valiev, Damir, OA

Varas, Stefano, 05, 1S

Vatnik, I. D., OF

Veber, A., 08

Velazquez, J. J., OB

Velmiskin, Vladimir V., 11

Vembris, Aivars, 1K

Vermillac, M., 1D

Vidal, S., 15

Vincetti, Luca, OW

Vitkin, Vladimir, $1 \mathrm{X}$

Volokitina, Anna, 1T, 1X

Voloshin, Andrey S., OS

Vyatkin, Mikhail Yu., 1Q

Walfort, B., 1C

Wessels, Peter, OY

Yehouessi, J.-P., 15

Yeung, Jerry, $1 \mathrm{M}$

Yushkov, Konstantin B., OS

Zajnulina, M., OJ

Zani, Maurizio, $1 \mathrm{G}$

Zaouter, Y., 15

Zarins, Elmars, $1 \mathrm{~K}$

Zehra, S. S., 19

Zhilin, Alexander, $1 \mathrm{x}$

Zonta, Daniele, 05

Zuppella, P., 19

Zur, Lidia, 09, OL

Zyryanova, Ksenia, OA 
Proc. of SPIE Vol. 11357 1135701-10 Downloaded From: https://www.spiedigitallibrary.org/conference-proceedings-of-spie on 26 Apr 2023
Terms of Use: https://www.spiedigitallibrary.org/terms-of-use 


\title{
Conference Committee
}

\author{
Symposium Chairs
}

Francis Berghmans, Vrijie Universiteit Brussel (Belgium)

Thierry Georges, Oxxius SA (France)

Paul Montgomery, Université de Strasbourg (France)

Lluis Torner, ICFO Barcelona (Spain)

\section{Conference Chairs}

Maurizio Ferrari, CNR-Istituto di Fotonica e Nanotecnologie (Italy) Jacob I. Mackenzie, University of Southampton (United Kingdom)

Stefano Taccheo, Politecnico di Torino (Italy) and Swansea University (United Kingdom)

\section{Conference Programme Committee}

Rolindes Balda, Universidad del Pais Vasco (Spain) John M. Ballato, Clemson University (United States)

Wilfried Blanc, Laboratoire de physique de la matière condensée (France)

Patrice Camy, Centre de Recherche sur les lons, les Matériaux et la Photonique (France)

Yanne K. K. Chembo, University of Maryland, College Park (United States)

Amol Choudhary, Indian Institute of Technology Delhi (India)

Cosimo D'Andrea, Politecnico di Milano (Italy)

Miroslav Dramicanin, University of Belgrade (Serbia)

Ulrich Hefter, ROFIN-SINAR Laser GmbH (Germany)

Shibin Jiang, AdValue Photonics, Inc. (United States)

Udo Klotzbach, Fraunhofer IWS Dresden (Germany)

Antti Lassila, MIKES Mittatekniikan Keskus (Finland)

Antonio Lucianetti, HiLASE Center (Czech Republic)

Anna Luiza Lukowiak, Institute of Low Temperature and Structure Research (Poland)

Virginie Nazabal, Université de Rennes 1 (France)

Nasser N. Peyghambarian, College of Optical Sciences, The University of Arizona (United States)

Francesco Prudenzano, Politecnico di Bari (Italy)

Alexander Quandt, University of the Witwatersrand (South Africa)

Gediminas Račiukaitis, Center for Physical Sciences and Technology (Lithuania)

Angela B. Seddon, The University of Nottingham (United Kingdom) 
Akira Shirakawa, The University of Electro-Communications (Japan)

Irina T. Sorokina, Norwegian University of Science and Technology (Norway)

\section{Session Chairs}

$1 \quad$ Flexible Photonics

Claudia Wickleder, Universität Siegen (Germany)

2 Glass Ceramics

Maurizio Ferrari, CNR-Istituto di Fotonica e Nanotecnologie (Italy)

3 Glass Ceramics and Short-range Ordered Materials

Wieslaw Strek, Institute of Low Temperature and Structure Research PAN (Poland)

4 RE-doped Material Lasers and Fibers

Anna Lukowiak, Institute of Low Temperature and Structure Research PAN (Poland)

5 RE-doped Material Spectroscopy: Glasses and Crystal

Maria Rita Cicconi, Friedrich-Alexander- Universität ErlangenNürnberg (Germany)

6 Nonlinear Phenomena in Fibres and Lasers

Francesco Prudenzano, Politecnico di Bari (Italy)

7 Waveguide Devices and Fibers

Jacob I. Mackenzie, University of Southampton (United Kingdom)

8 Fiber Lasers: from IR to MIR

Nikolai Tolstik, Atla Lasers AS (Norway)

9 2-micron Fiber Lasers: Joint Session I

Udo Klotzbach, Fraunhofer-Institut für Werkstoff- und Strahltechnik IWS (Germany)

10 Active Fibers for 2-micron Fiber Lasers: Joint Session II

Pavel Peterka, Institute of Photonics and Electronics of the CAS, v.v.i. (Czech Republic)

11 Applications and Processes

Isabel Kinski, Fraunhofer-Institut für Keramische Technologien und Systeme IKTS (Germany) 
12 Materials and Fibers: Characterization, Fabrication and Applications Mariola O. Ramirez, Universidad Autónoma de Madrid (Spain)

13 Novel Materials and Devices

Stefano Taccheo, Politecnico di Torino (Italy) 
Proc. of SPIE Vol. 11357 1135701-14 Downloaded From: https://www.spiedigitallibrary.org/conference-proceedings-of-spie on 26 Apr 2023
Terms of Use: https://www.spiedigitallibrary.org/terms-of-use 